УДК 621.43

DOI: https://doi.org/10.26642/ten-2020-2(86)-13-17

Р.В. Колодницька, к.т.н., доц.

Державний університет «Житомирська політехніка»

\title{
Моделювання затримки займання дизельного біопалива
}

Шкідливі викиди та викиди вуглекислого газу, зокрема внаслідок згоряння дизельного викопного палива, є причинами обмеження його використання для автомобільного транспорту у низці країн світу. Тому використання дизельного біопалива у двигуні внутрішнього згоряння (ДВЗ) автомобільного транспорту є актуальним питанням. Для покращення згоряння біопалива необхідно дослідити затримку його займання. В роботі запропоновано моделювання затримки займання дизельного біопалива за допомогою двох рівнянь Арреніуса залежно від діапазону температури. Для низьких та середніх температур затримка займання залежить від типу палива, тому рівняння містить цетанове число палива. Для високих температур, здебільшого, затримка займання не залежить від типу палива. Під час моделювання процесу згоряння реальне біопаливо замінюють одним компонентом або сумішию декількох компонентів. Це - метиловий деканоат (метилдеканоат $\mathrm{C}_{11} \mathrm{H}_{22} \mathrm{O}_{2}$ ), кислота якого має десять атомів вуглецю (С10:0М) та два метилові ефіри з одним подвійним зв'язком, щзо розташовані в різних положеннях аліфатичного основного ланиюга: метил-5-децеонат (C10:1M5) $i$ метил-9-децеонат (C10:1М9). Виконано моделювання затримки займання компонентів дизельного біопалива, щяо використовуються для моделювання згоряння палива. Дослідження затримки займання (С10:1M9) засвідчили, щзо ией ефір не підходить як компонент сурогату дизельного біопалива через його подібну реакційну активність з (С10:0М). Одержано гарне узгодження теоретичних значень затримки займання 3 експериментальними даними для метилдеканоат $\mathrm{C}_{11} \mathrm{H}_{22} \mathrm{O}_{2}$ та метил-5-децеонат (С10:1M5). Як замінник дизельного біопалива у задачах моделювання згоряння біопалива в ДВЗ автомобільного транспорту можна використовувати сурогатне паливо з 41,18\% н-декану, 9,41 \% (С10:0М) та 49,41\% (C10:1M5). Дослідження затримки займання такого сурогатного палива може бути темою подальших досліджень.

Ключові слова: автомобільний транспорт; дизельне біопаливо; біодизель; затримка займання.

Постановка проблеми. Шкідливі викиди від згоряння дизельного викопного палива, що використовується у ДВЗ для автомобільного транспорту, - одна із причин обмеження його використання у низці країн Свропейського Союзу та світу. Водночас сьогодні обмежено використання всіх викопних палив через глобальне потепління, однією із причин якого є збільшення викидів парникових газів, зокрема $\mathrm{CO}_{2}$. Частково ці проблеми можна вирішити завдяки використанню дизельного біопалива (біодизеля) [1]. В Європі біодизельне паливо випускається комерційно. Є багато енергетичних компаній (наприклад, «Брітіш Петроліум»), що обов'язково додають у дизельне паливо певний відсоток біодизельного. Біодизельне паливо виготовляється з рослин, які поглинають вуглекислий газ. Це паливо має менші викиди сажі, ніж дизельне і не містить канцерогенів у своєму складі. Кількість оксидів азоту, що викидає це біопаливо, можна зменшити додаванням наночастинок. Тому дослідження використання дизельного біопалива в ДВЗ автомобільного транспорту є актуальним завданням. Дизельне біопаливо, що переважно використовується як домішка до дизельного палива, - це, здебільшого, суміш метилових ефірів жирних кислот [1-3]. Кількість ефірів жирних кислот, що входять до складу метилового ефіру соєвої олії та метилового ефіру ріпакової олії, змінюється від 5 до 15. У $[1,3,4]$ описано властивості біодизельних палив та характеристик розпилювання цих палив.

Одна із проблем, яка до цього часу ще не досить детально досліджена, - це згорання дизельного біопалива у ДВ3 i, частково, затримка займання цього палива. Деякі виконані дослідження згоряння дизельного біопалива та експериментальні дослідження затримки займання наведено в роботах $[2,5,6]$.

Оскільки згоряння палива досить складний процес, для спрощення розрахунків реальне паливо замінюють одним компонентом або сумішшю декількох компонентів, що має назву сурогатне паливо. Найпростіший компонент - це метиловий деканоат (метилдеканоат $\mathrm{C}_{11} \mathrm{H}_{22} \mathrm{O}_{2}$ ), кислота якого має десять атомів вуглецю (C10:0M). Метилові ефіри жирних кислот зазвичай позначають, вказуючи кількість атомів вуглецю жирної кислоти, що розміщують після букви «С», і кількість подвійних зв'язків - після «:». Отже, метилдеканоат (C10:0M), який часто використовують у моделях згоряння, не має подвійних зв'язків, на відміну від більшості фактичних компонентів біодизеля. Тому потрібно дослідити окислення двох С10метилових ефірів 3 одним подвійним зв'язком, що розташовані в різних положеннях аліфатичного основного ланцюга: метил-5-децеонат (C10:1M5) і метил-9-децеонат (C10:1M9). 
Дослідження [7] свідчать, що (C10:1M9) не підходить для сурогату дизельного біопалива через його подібну реакційну активність 3 (C10:0M). Чанг та ін. [8] запропонували сурогатну модель біодизеля, що $\epsilon$ сумішшю 3 н-декану та двох метилових ефірів: (C10:0M) та (С10:1M5). Метилові ефіри (C10:0M) та (C10:1M5) були обрані для представлення насиченого метилового ефіру та ненасиченого метилового ефіру, відповідно. Останній компонент, н-декан, був обраний для відповідності енергетичному вмісту та співвідношенню $\mathrm{C} / \mathrm{H} / \mathrm{O}$ фактичного біодизельного палива [7].

Мета роботи - моделювання затримки займання компонентів дизельного біопалива.

Викладення основного матеріалу. Здебільшого затримка займання (відрізок часу від початку впорскування до займання палива) моделюється за допомогою рівнянь Арреніуса. Але моделювання затримки займання біопалива одним рівнянням не показало збігу з експериментальними даними. В цій роботі затримка займання дизельного біопалива моделювалася за допомогою двох рівнянь залежно від діапазону температури.

Для низьких температур затримка займання (ID) залежить від типу палива, тому рівняння (1) містить цетанове число палива:

$$
I D=A_{\text {act }}\left(\frac{50}{C N}\right)^{1,5} \frac{1[\mathrm{~atm}]}{p} \exp \left(\frac{T_{a c t}}{T}\right),
$$

де $A_{\text {act }}$ - активаційний коефіцієнт (мс); $C N$ - цетанове число палива; $p$ - тиск у циліндрі (атм); $T_{a c t}-$ активаційна температура, К; $T$ - температура, К.

Для середнього діапазону температур також використовується рівняння (1), але 3 негативною активаційною температурою $T_{a c t}$. Для високих температур, здебільшого, затримка займання не залежить від типу палива, тому цетанове число не є частиною рівняння для моделювання:

$$
I D=A_{\text {act }} \frac{1[a t m]}{p^{0,8}} \exp \left(\frac{T_{a c t}}{T}\right) .
$$

На рисунку 1 показана затримка займання для компонента (C10:0М) за тиску 20 атм, використовуючи рівняння (1-2), порівняно з експериментальними даними, взятими з роботи [9]. Відповідно до [10] цетанове число для компонента (С10:0М) становить 51,0.

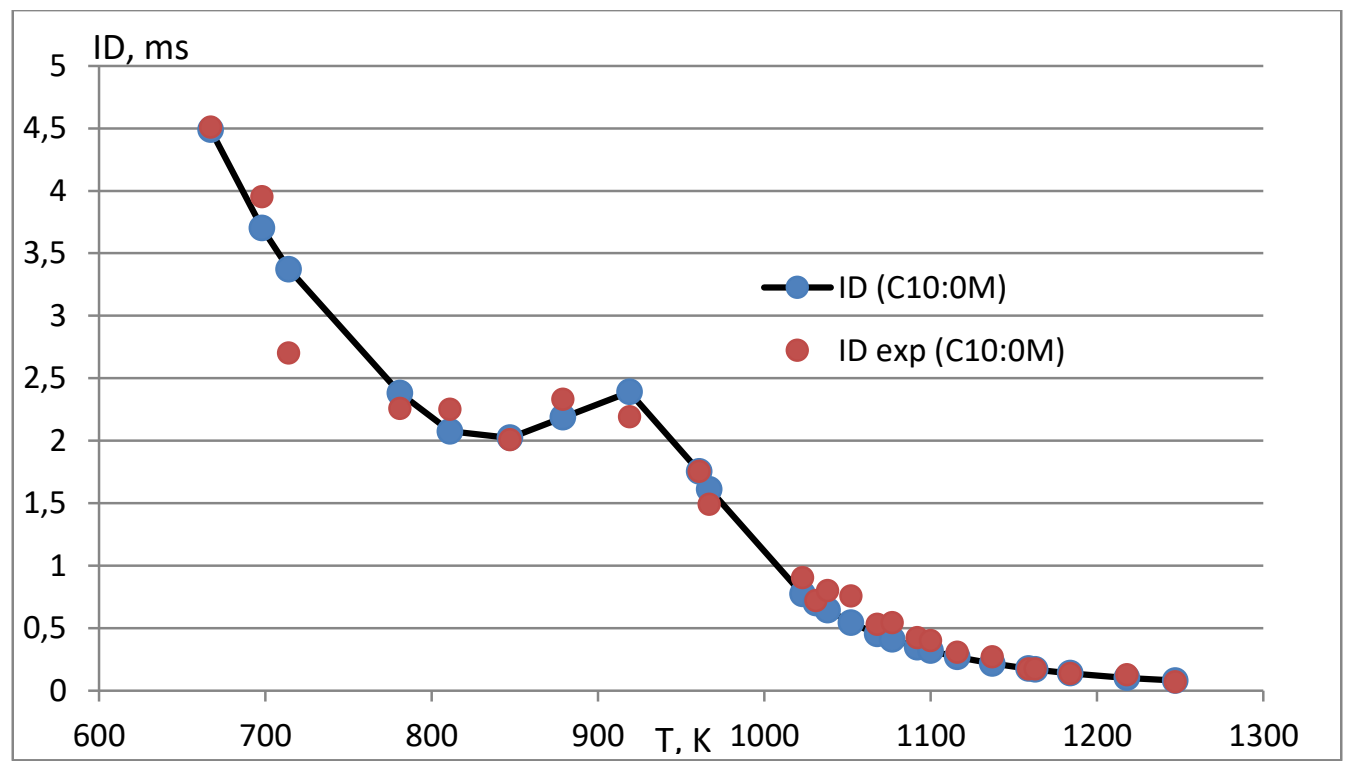

Рис. 1. Затримка займання (мс) метилового ефіру (С10:0М) залежно від температури

Для моделювання затримки займання $(\mathrm{C} 10: 0 \mathrm{M})$ використовувалися такі коефіцієнти: для низьких температур $\left(A_{\text {act }}=1,20 \mathrm{mc}, T_{a c t}=2900 \mathrm{~K}\right)$, середніх температур $\left(A_{a c t}=350 \mathrm{мc}\right.$ та $\left.T_{\text {act }}=-1800 \mathrm{~K}\right)$ та для високих температур $\left(A_{a c t}=2,57 \mathrm{E}-05\right.$ мс та $\left.T_{a c t}=1300 \mathrm{~K}\right)$.

На рисунку 2 показано порівняння затримки займання для двох складових компонентів сурогатного палива: метилового ефіру насиченої кислоти $(\mathrm{C} 10: 0 \mathrm{M})$ та метилового ефіру кислоти з одним подвійним зв'язком (С10:1M9). Цетанове число для (С10:1М9) становить 31,0. 


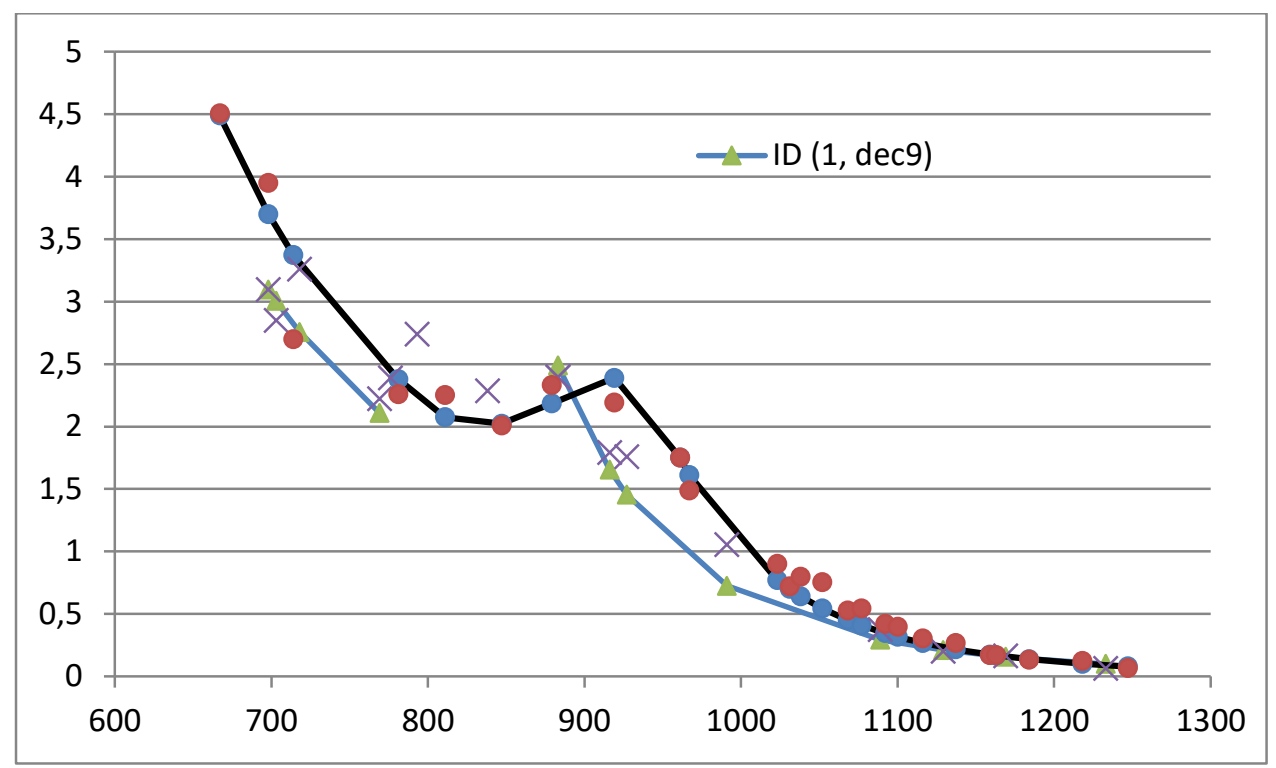

Рис. 2. Порівняння затримки займання для двох компонентів сурогатних палив: (C10:0M) та (C10:1M9) (позначення ID (1, dec 9))

Для високих температур рівняння (2) для компонента (C10:1M9) знайдено коефіцієнти: $A_{a c t}=3,30 \mathrm{E}-04$ мс, $T_{a c t}=10000$ К. Як бачимо з рисунка 2, кінетика двох компонентів - (C10:1M9) та (C10:0М) - сурогатного палива дуже схожа. Хоча за низьких температур кінетика (C10:1M9) дуже нестійка, можна спостерігати також ділянку негативної кінетичної енергії, як і в компоненті (C10:0M).

На рисунку 3 показано затримку займання для компонента (C10:1M5) 3 коефіцієнтами для високих температур $A_{a c t}=6,82 \mathrm{E}-05$ мс, $T_{a c t}=11350 \mathrm{~K}$. Як видно з рисунку 3 , затримка займання цього компонента не має від'ємної активаційної енергії.

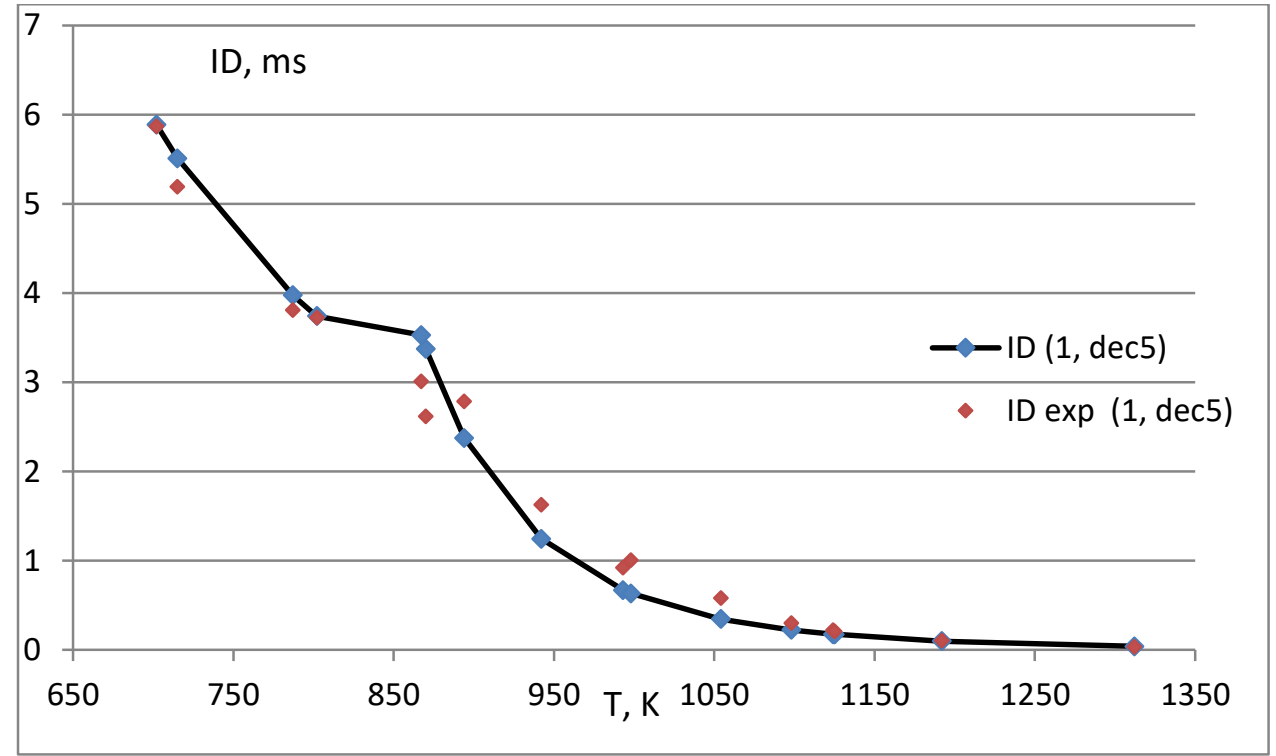

Рис. 3. Затримка займання (мс) метилового ефіру (С10:1M5) залежно від температури

На рисунку 4 показано порівняння затримки займання компонентів (C10:0M) та (C10:1M5) біодизельного палива. 


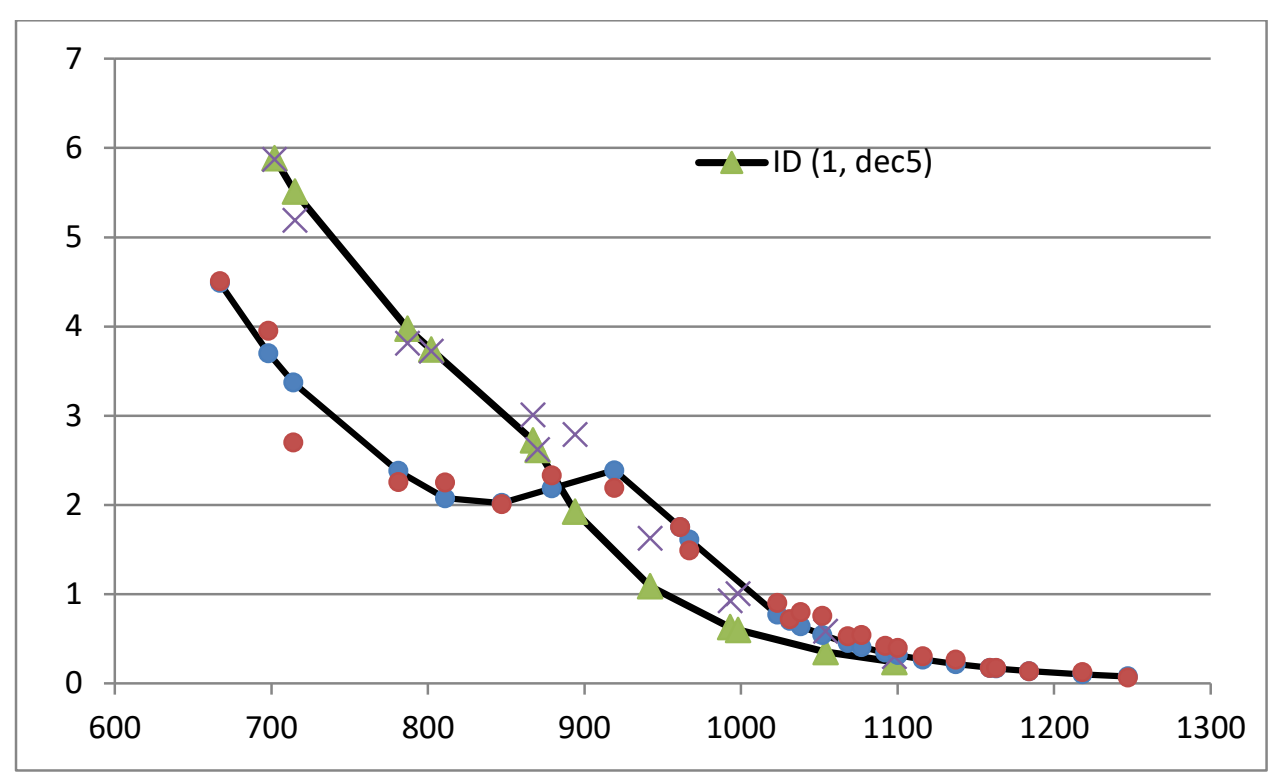

Рис. 4. Затримка займання метилового ефіру (мс) (С10:1M5) та (C10:0M) залежно від температури

Як показано в роботі [8], займання та окислення соєвого біодизельного палива можна моделювати за допомогою сурогатної моделі з 41,18 \% н-декану, 9,41% (C10:0М) та 49,41% (C10:1М5). Дослідження затримки займання такого сурогатного палива може бути темою подальших досліджень.

Висновки. Виконано моделювання затримки займання дизельного біопалива за допомогою двох рівнянь Арреніуса залежно від діапазону температури. Проаналізовано експериментальні дані з затримки займання компонентів, що містяться у складі сурогату (тобто замінника) дизельного біопалива для його використання у моделях згоряння палива. Для моделювання затримки займання метилового деканоату $(\mathrm{C} 10: 0 \mathrm{M})$ використовувалися такі коефіцієнти: для низьких температур $\left(A_{a c t}=1,20 \mathrm{мc}, T_{a c t}=2900 \mathrm{~K}\right)$ та для високих температур $\left(A_{a c t}=2,57 \mathrm{E}-05\right.$ мс та $\left.T_{a c t}=1300 \mathrm{~K}\right)$. Для високих температур компонентів $(\mathrm{C} 10: 1 \mathrm{M} 9)$ та (C10:1M5) було знайдено значення коефіцієнтів $-\left(A_{\text {act }}=3,30 \mathrm{E}-04 \mathrm{мc}, T_{a c t}=10000 \mathrm{~K}\right)$ та $\left(A_{a c t}=6,82 \mathrm{E}-05 \mathrm{мc}, T_{a c t}=11350 \mathrm{~K}\right)$ відповідно. Моделювання затримки займання компонентів сурогату дизельного біопалива добре узгоджується з експериментальними даними.

\section{Список використаної літератури:}

1. Колодницька Р.В. Розпилювання дизельного палива та біопалива у двигунах внутрішнього згоряння : монографія / Р.В. Колодницька. - Житомир : ЖДТУ, 2017. - 210 с.

2. Колодницька Р.В. Процеси випаровування та згоряння дизельного біопалива у двигунах внутрішнього згоряння : монографія / Р.В. Колоднииька. - Житомир : ЖДТУ, 2018. - 192 с.

3. Грабар І.Г. Біопалива на основі олій для дизельних двигунів : монографія / І.Г. Грабар, Р.В. Колоднищька.Житомир : ЖДТУ, 2011. - 152 с.

4. Колодницька P.В. Відновлювальне дизельне паливо та синтетичне паливо як альтернатива для дизельного палива / Р.В. Колоднищька, О.П. Кравченко // Вісник Житомирського державного технологічного університету. Серія : Технічні науки. - 2019. - № 1 (83). - С. 3-11.

5. Колодницкая P.B. Анализ влияния углеводородного состава биодизельного топлива на показатели рабочего процесса дизельных двигателей / Р.В. Колодницкая, Г.А. Вершина, А.Ю. Пилатов // Вісті автомобільнодорожнього інституту. - 2011. - № 1 (121). - С. 118-128.

6. Колодницкая P.B. Моделирование технико-экономических показателей рабочего процесса биодизеля на основе растительных масел морских водорослей / Р.В. Колодницкая, А.Ю. Пилатов // Вестник СевГТУ. Серия : Машиноприборостроение и транспорт. - Севастополь : СевНТУ, 2012. - Вып. 134. - С. 191-194.

7. Yang S. A Bio-Diesel Chemical Kinetic Mechanism Based on Decoupling Methodology and Detailed H2/O2/CO/C1 C3 Mechanism / S.Yang, M.Jia // Frontiers in Mechanical Engineering. - 2019. - Vol. 5, Art. 21. DOI: 10.3389/fmech.2019.00021.

8. Development of a skeletal oxidation mechanism for biodiesel surrogate / Y.Chang, M.Jia, Y.Li and other // Proceedings of the Combustion Institute. - 2015. - № 35. - P. 3037-3044.

9. Wang W. Comparative Study of the Autoignition of Methyl Decenoates, Unsaturated Biodiesel Fuel Surrogates / W.Wang, S.Gowdagiri, M.A. Oehlschlaeger // Energy Fuels. - 2013. - Vol. 27, Issue 9. - P. 5527-5532.

10. Giakoumis E.G. Comparative Assessment of Biodiesel Cetane Number Predictive Correlations Based on Fatty Acid Composition / E.G. Giakoumis, C.K. Sarakatsanis // Energies. - 2019. - № 12. - P. 422. DOI: 10.3390/en12030422. 


\section{References:}

1. Kolodnyc'ka, R.V. (2017), Rozpyljuvannja dyzel'nogo palyva ta biopalyva u dvygunah vnutrishn'ogo zgorjannja, monografija, ZhDTU, Zhytomyr, $210 \mathrm{p}$.

2. Kolodnyc'ka, R.V. (2018), Procesy vyparovuvannja ta zgorjannja dyzel'nogo biopalyva u dvygunah vnutrishn'ogo zgorjannja, monografija, ZhDTU, Zhytomyr, $192 \mathrm{p}$.

3. Grabar, I.G. and Kolodnyc'ka, R.V. (2011), Biopalyva na osnovi olij dlja dyzel'nyh dvyguniv, monografija, ZhDTU, Zhytomyr, $152 \mathrm{p}$.

4. Kolodnyc'ka, R.V. and Kravchenko, O.P. (2019), «Vidnovljuval'ne dyzel'ne palyvo ta syntetychne palyvo jak al'ternatyva dlja dyzel'nogo palyva», Visnyk Zhytomyrs'kogo derzhavnogo tehnologichnogo universytetu, Serija Tehnichni nauky, No. 1 (83), pp. 3-11.

5. Kolodnitskaya, R.V., Vershina, G.A. and Pilatov, A.Yu. (2011), «Analiz vliyaniya uglevodorodnogo sostava biodizel'nogo topliva na pokazateli rabochego protsessa dizel'nykh dvigatelei», Visti avtomobil'no-dorozhn'ogo instytutu, No. 1 (121), pp. 118-128.

6. Kolodnitskaya, R.V. and Pilatov, A.Yu. (2012), «Modelirovanie tekhniko-ekonomicheskikh pokazatelei rabochego protsessa biodizelya na osnove rastitel'nykh masel morskikh vodoroslei», Vestnik SevGTU, Serija Mashinopriborostroenie i transport, SevNTU, Sevastopol', Issue 134, pp. 191-194.

7. Yang, S. and Jia, M. (2019), «A Bio-Diesel Chemical Kinetic Mechanism Based on Decoupling Methodology and Detailed $\mathrm{H} 2 / \mathrm{O} 2 / \mathrm{CO} / \mathrm{C} 1 \sim \mathrm{C} 3$ Mechanism», Frontiers in Mechanical Engineering, Vol. 5, Art. 21, doi: 10.3389/fmech.2019.00021

8. Chang, Y., Jia, M., Li, Y. and other (2015), «Development of a skeletal oxidation mechanism for biodiesel surrogate», Proceedings of the Combustion Institute, No. 35, pp. 3037-3044.

9. Wang, W., Gowdagiri, S. and Oehlschlaeger, M.A. (2013), «Comparative Study of the Autoignition of Methyl Decenoates, Unsaturated Biodiesel Fuel Surrogates», Energy Fuels, Vol. 27, Issue 9, pp. 5527-5532.

10. Giakoumis, E.G. and Sarakatsanis, C.K. (2019), «Comparative Assessment of Biodiesel Cetane Number Predictive Correlations Based on Fatty Acid Composition», Energies, No. 12, pp. 422, doi: 10.3390/en12030422

Колодницька Руслана Віталіївна - кандидат технічних наук, доцент кафедри автомобілів і транспортних технологій Державного університету «Житомирська політехніка».

Наукові інтереси:

- $\quad$ альтернативні палива та біопалива для автомобільного транспорту;

- розпилювання, випаровування та згоряння палива у ДВЗ;

- шкідливі викиди автомобільного транспорту.

E-mail: ruslanakolod2017@gmail.com. 